\title{
FILMSTADT IN THE VORSTADT: \\ LOCATIONALITY IN THE \\ FILMMAKING PRACTICE OF \\ MIHÁLY/ MICHAEL KERTÉSZ/ CURTIZ
}

SUSAN INGRAM | YORK UNIVERSITY

The article examines the largest and most monumental of the silent film epics produced in the Austrian republic: Sodom und Gomorrha (1922). In seeking out the film's shooting location, an abandoned site of clay pits and hilly grasslands at the southern edge of Vienna, the article explores what the site's history and current incarnation as part of a Kurpark reveal about the filmmaker's urban imaginary and the role of technology in modernizing it, and it establishes parallels between the early work he did under the name Michael Kertész and the later success of his cult classic Casablanca.
Cet article examine le plus monumental film muet produit dans la république d'Autriche: Sodom und Gomorrha (1922). Avec l'exploration du site de tournage du film, une enclave de grès et de friches à la frontière sud de Vienne, on examine comment l'histoire passée du site et son incarnation actuelle comme Kurpark révèlent l'imaginaire urbain du cinéaste et le rôle de la technologie dans sa participation à la modernité. On établit en outre certain parallèles entre les premiers films qu'il a réalisés sous le nom de Michael Kertész et le succès plus tardif de son film-culte Casablanca. 
In Vienna in the aftermath of World War I, amidst an economic crisis that resulted in hyperinflation, mass unemployment, and political radicalization, silent film epics were produced of monumental scale with themes taken from history, the Old Testament and classical antiquity. One of the largest and most monumental of these films, and the most expensive film ever produced in Austria, was the 1922 Sodom und Gomorrha directed by Michael Kertész, as he was then called.[1] The film juxtaposes a contemporary story of seduction, sin and redemption with a biblical tale that could be mobilized for designing, constructing and spectacularly destroying lavish, art deco-inspired sets of gigantic proportion.

The film is spectacular in many regards, and not simply for its production values or the brilliant restorative work that the Filmarchiv Austria did to make 98 minutes of the original three-hour-long production available in 2002 (Nord). [2] As will be shown here, Sodom und Gomorrha not only substantiates claims like Loacker and Steiner's about film's suitability for creating and preserving images but also shows that even early film was able to interact with and affect the places it created and preserved images of.[3] Sodom und Gomorrha is an unsung touchstone in cinematic history that allows one to open up new perspectives on, and relations between, classics like Metropolis (1927, dir.

Fritz Lang) and Casablanca (1942, dir. Michael Curtiz) if one is willing to make a small detour through the outskirts of Vienna to its main filming location, which is the path this article takes. In resituating Sodom und Gomorrha in the place where it was made, this contribution taps into and reveals the film's emancipatory potential for a film historiography that is expanding to take in copies of long-lost films that have been resurfacing out of the archives of Eastern Europe.

It also adds to the scholarship on Curtiz, whose underappreciation is underscored in the few biographical studies of him there are (cf. Portuges, Robertson) and by the title of the 2012 documentary, Michael Curtiz: The Greatest Director You Never Heard Of. When Curtiz's films receive attention, it is usually on account of their thematics, such as the nostalgia in Casablanca that interested Homi Bhabha and Umberto Eco, among others. Both Film Studies and Austrian Studies tend to be dismissive of Curtiz's accomplishments, and allusions and references to his work are often overlooked. To cite a recent example, in an article on Billy Wilder's Austrian connections, Robert Dassanovsky attributes the "true name of the helpless Belgian wife searching for her missing husband in Wilder's truncated Sherlock Holmes tribute," namely, Ilse von Hofmannsthal, to "the equally untrustworthy femme fatale (Marlene Dietrich) in A Foreign Affair (1948)" because that character "insists on the recognition of her nobility (the von in her name) in the very same manner" (Dassanovsky 5). Rather than referring to Erika von Schluetow, whom Wilder, like everyone else, would associate with Berlin, something at odds with the allusion to Vienna in the last name to 
"Austria's most anti-Prussian Viennese author (Hugo von Hofmannsthal, 18741929)" (6), a stronger case for a Viennese/ Central European connection could be made by not ignoring but rather positing that Wilder was alluding to the heroine in Curtiz's 1942 Casablanca, Ilsa Lund, and then referencing Curtiz's career as I do here. In revealing Kertész/ Curtiz's minoritarian proclivity for peripheral locations and the potentiality of technology, this article draws attention to hitherto underappreciated aspects that demonstrate the consistency and coherence of the filmmaker's progressive oeuvre.

\section{Sodom und Gomorrha}

One of Sodom und Gomorrha's many remarkable qualities is the complexity of its plot structure. It may begin conventionally enough with the archetypical story of a beautiful young girl (Miss Mary Conway, Fig. 1), whose mother pressures her into renouncing the well-known sculptor she is in love with (Harry Lighton, Fig. 2) in order to marry an evil capitalist (Mr. Harbers, Fig. 3), who is old enough to be her father and has just caused the London Stock Exchange to crash to his benefit.

Two plot twists are then introduced. First, there is a flashback to the biblical city of Sodom, which is depicted as a parallel to contemporary hedonistic Vienna. This link is made explicit with the same actress who plays Mary playing Lot's wife (both parts are played by Kertész's then wife, Lucy Doraine) as well as in the intertitles that precede the shift to Sodom. When Mary catches sight of them building

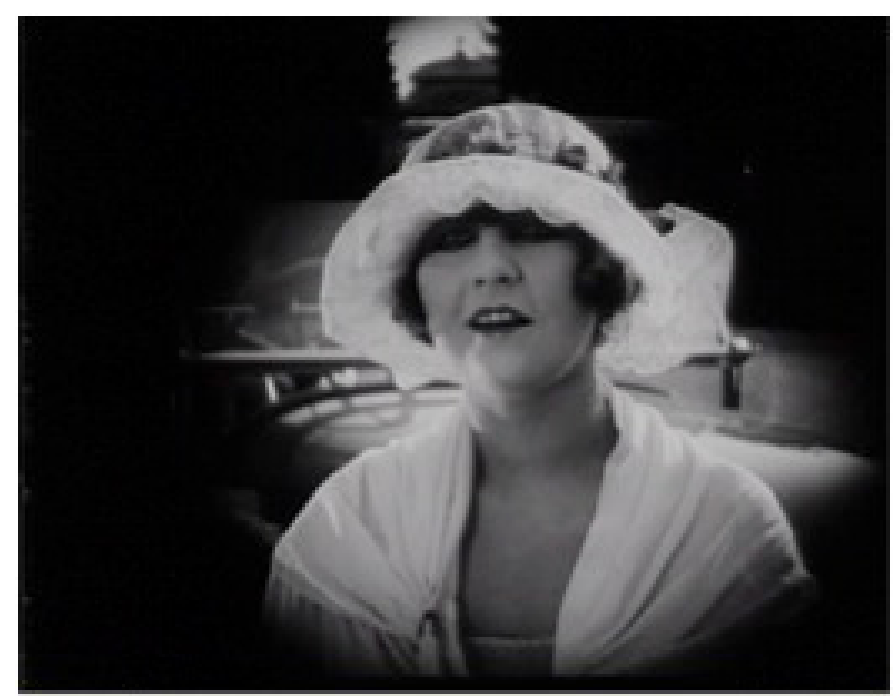

Fig. 1 Mary Conway

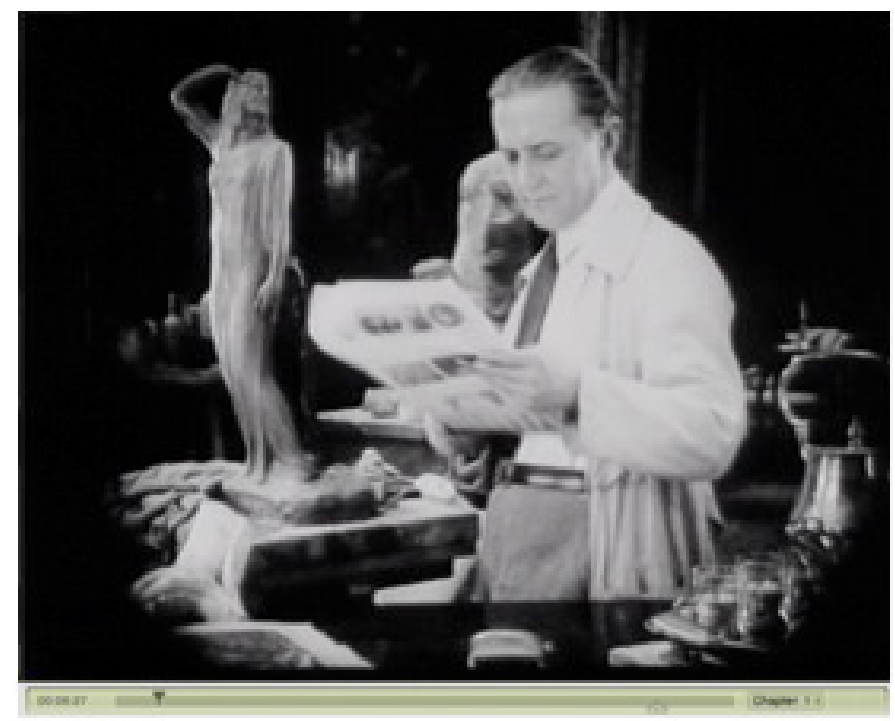

Fig. 2 Harry Lighton

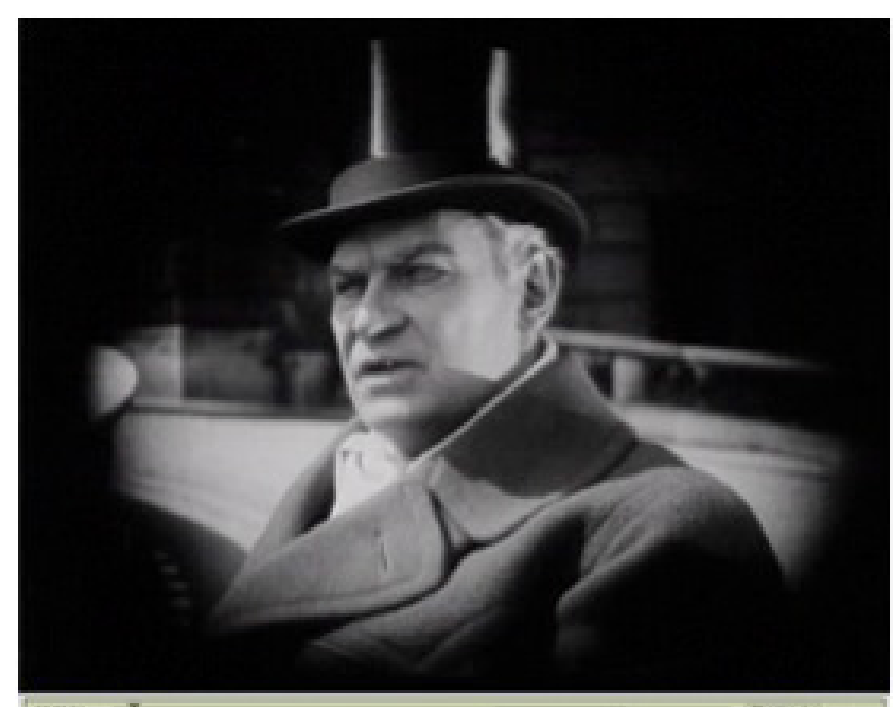

Fig. 3 Mr Harbers 
her "Blutgerüst," she throws herself at the priest, who replies: "You, daughter of Sodom! Even in your last moments you're thinking only of your sinful body and not of freeing your soul?!" "Suffering world, you new Sodom and Gomorrah" "You are ripe for destruction!" "In your palaces orgies are held just as they were in Lot's city...!” („Du Tochter Sodoms! Auch in Deinen letzten Augenblicken denkst Du nur an Deinen sündhaften Körper und nicht an die Befreiung Deiner Seele?!“ „Wehe Dir, elende Welt, Du neues Sodom und Gomorrrha! Du bist reif, um vernichtet zu werden.“ „In Deinen Palästen feiert das Laster Orgien wie einstmals in der Stadt des Lot...!").

In the second plot twist, just as Lot's wife looks back and is turned into a pillar of salt, we discover that a good part of Mary's adventures before the flashback to Sodom has been a dream. She is shown waking up in terror and smiling when she recognizes that she is not in the jail cell she was taken to for inciting Mr Harber's son Eduard to stab his father, but rather the bedroom of the palatial villa where her wild engagement party took place, at which Harry threatened to shoot himself and Mary then, in what turns out to have been a dream sequence, went about seducing both Eduard and his priestguardian. When we return to Mary at the end of the film, she looks at a clock and declares that in the past half hour she has experienced a terrible tragedy („In einer halben Stunden durchlebte ich eine fürchterliche Tragödie“), forcing the viewer to think back over the course of the film to determine the point at which the apparent reality of the filmic narrative had actually become a dream.
Also noteworthy is the film's situating of Mary as a dreamer-protagonist, something that warrants a comparison with Metropolis (1927, dir. Fritz Lang). Andreas Huyssen has suggested that "it is precisely the doubling of Maria, the use of religious symbolism, the embodiment of technology in a woman-robot and Freder's complex relationship to women and machines, sexuality and technology, which give us a key to [Metropolis's] social and ideological imaginary" (66). Sodom und Gomorrha also features a doubling of the female protagonist, religious symbolism and a father-son rivalry; however, it is not about the son's complex relationship to women, machines, sexuality and technology, but rather the woman's complex relationship to men, technology, urbanity, and history. It is not a case of a female heart mediating in a Tower of Babel conflict between a clearly class-based male head and hands, but rather of a female soul trying to make her way through depraved surroundings and mediate between the waking dream of her phantasmagorical consumer-based existence and what her dream teaches her about her heart. There are not two Marys in Sodom und Gomorrha the way there are two Marias in Metropolis: one innocent, pristine and bucolic, the other a vampish machine that wreaks havoc and destruction on a city. Rather both Mary and Lot's wife Sarah are vampish, lascivious temptresses, but their lasciviousness is not destructive, only self-destructive. Sodom is destroyed not by one woman's desires but rather by the general mores of the place. In other words, it is not a fear of woman per se, but a woman's fears that are the central 
concern in Kertész's film, something with political implications. As Huyssen has shown, the fear of woman in Metropolis is also a fear of the masses:

The fear of the masses in this age of declining liberalism is always also a fear of woman, a fear of nature out of control, a fear of the unconscious, of sexuality, of the loss of identity and stable ego boundaries in the mass. [...] Male fears of an engulfing femininity are here projected onto the metropolitan masses, who did indeed represent a threat to the rational bourgeois order. The haunting specter of a loss of power combines with fear of losing oness fortified and stable ego boundaries, which represent the sine qua non of male psychology in that bourgeois order. (52-3)

What then of female fears? By equating Mary and Lot's wife, Sodom und Gomorrha shows how women have been barred from accessing technologically driven progress. The only resource Mary has to mobilize is depicted as precisely the same as in the biblical tale: namely, her decidedly low-tech womanly charms. Kertész's film encourages one to conclude that the female lot in life, if one may be permitted to put it like that, has not improved over the millennia. Rather, it is up to women to learn from the bad dream that has historically been their reality and wake up and follow their hearts.

It is here that the film implicitly makes a neat leap. After all, if women are to learn from their dreams, then where better for them to turn than the dream factory of cinema? In staging an intricate example of pedagogy, Kertész can be seen to be raising awareness of the potential of the new technology to motivate emancipatory dreams, something that is mirrored in his own production practice. Kertész obviously did not feel the need to depict either the unruly masses or technology as a threat the way the much more bourgeois Fritz Lang and Thea von Harbou did. As Huyssen reminds us:

The expressionist view emphasizes technology's oppressive and destructive potential and is clearly rooted in the experiences of the mechanized battlefields of World War I. During the 1920s and especially during the stabilization phase of the Weimar Republic this expressionist view was slowly replaced by the technology cult of the Neue Sachlichkeit and its unbridled confidence in technical progress and social engineering. Both these views inform [Metropolis]. (67)

Kertész, who had been born in Budapest in 1886 and would die in Los Angeles in 1962 , seems to have sided more solidly with the latter view. His filmmaking practice shows him to have been aware of the powerful good that his medium of choice could do. His monumental films employed literally thousands at a time when unemployment in Vienna was rampant, as films like the Greta Garbo vehicle Die freudlose Gasse/ Joyless Street made a point of depicting by ostensibly setting the misère in Vienna (though the film was actually made in Berlin). 


\section{Sodom und Gomorrha's Location}

The site Kertész chose for the most spectacular sequences in his film also reflects the attention he paid to film's, and technology's, emancipatory potential. While previous films made for Sascha Films were shot either in the Prater or a studio in Sievering (Loacker 31), Sodom und Gomorrha required an uninhabited area with hills and ponds, upon which huge sets could be built and destroyed without inconveniencing surrounding dwellings. A suitable location was found in what has come to be called the "Filmstadt" [Fig. 4] in honour of the films made there in the 1920s. The Filmstadt is part of the Kurpark Oberlaa [Figs. 5 and 6], which is located on the Laaerberg in Favoriten, Vienna's tenth district and one of the most proletarian parts of its Vorstadt (the title of the standard work on the subject Die Anarchie der Vorstadt: Das andere Wien um 1900 by Wolfgang Maderthaner and Lutz Musner has been translated into English as Unruly Masses. The Other Side of Fin-de-Siecle Vienna). [4] This other/ outer part of Vienna has tended to be neglected, especially in Anglophone scholarship, as it is hard to square with, and can only detract from or call into question what has become known as the myth of "Vienna 1900," which is firmly located along the central Ringstrasse that Franz Joseph had built in the mid nineteenth century around the city's first district to replace the city's premodern military defensive glacis, which is where Kertész's film starts. However, there is only an establishing shot of the centre, after which Kertész takes us to the city's monumental

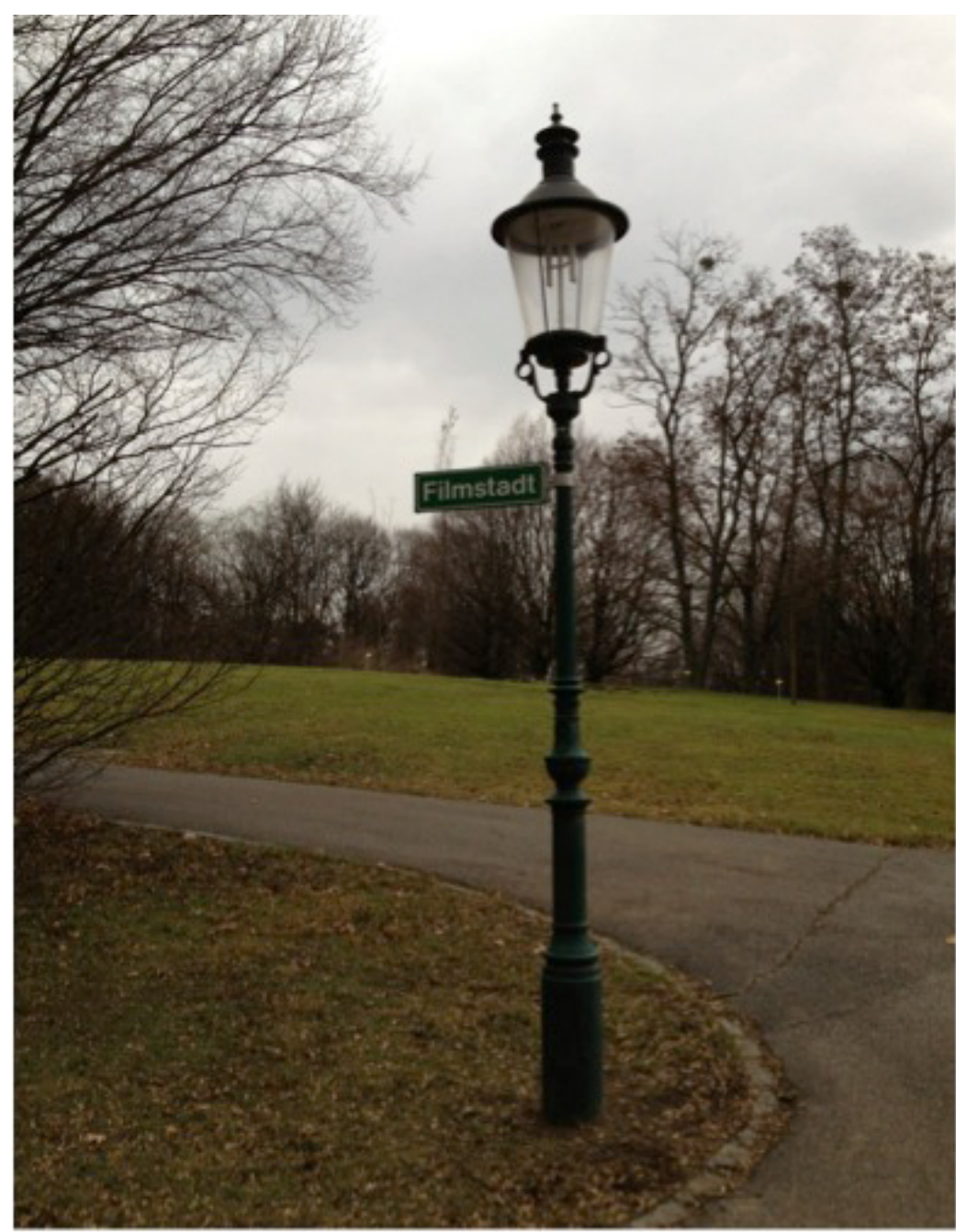

Fig. 4 Filmstadt

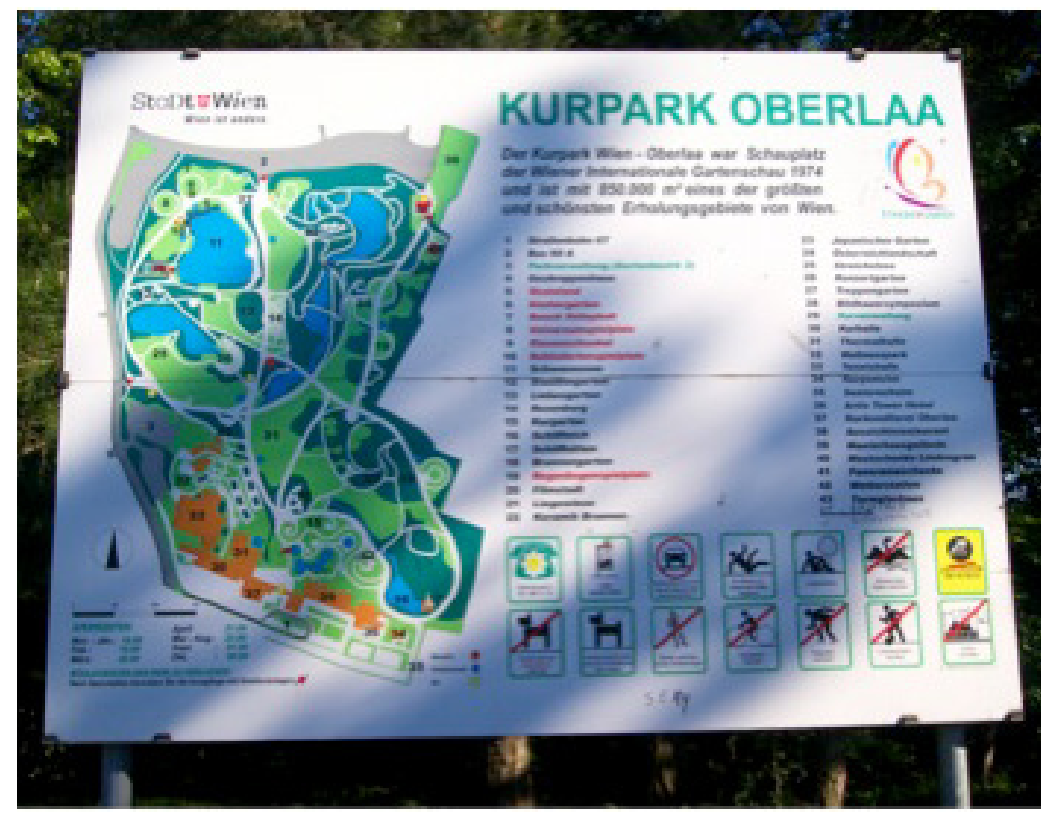

Fig. 5 Kurpark Oberlaa, \#20 Filmstadt 
was established in 1874 from the increasingly proletarianized parts of the third, fourth and fifth districts. Through the operation of land prices, an 'economy based on division of labor' had led 'under profit pressures' to 'a functional specialization of the urban space' as well as a 'marked social segregation of the population.' The steady expansion of development took place according to a strict pattern in which housing and industrial plots intermingled. On the edge of the Wienerberg and Laaerberg hills there thus grew up what was for Viennese standards a uniquely homogeneous and dynamically expanding quarter. Medium-sized plants in metalworking and machine-building in particular were built here, as well as the innovative and capital-intensive electrical industry, without breaking the prescribed blockgrid system. (41)

A direct product of industry, the area, "which mushroomed in open country in the wake of the railroad construction" (41), became "a virtual refuge for numerous families who had no other resources but their children, could not manage to exist in other parts of the city given the significantly higher rents and provision costs, and were pressed into the low-rent tenth district" (Lichtenberger, cited in Maderthaner and Musner 42, Fig. 7).

According to former inhabitants interviewed by Robert Wegs, prior to WWII Favoriten comprised three distinct social and cultural areas:
The eastern part of the district, overlooked by the Ankerbrotfabrik (which became the largest bread factory in the world in the 1920s), was described by most of those I interviewed as the poorest part of Favoriten in the pre-WWI period. Known as Kreta to most local inhabitants, it housed many of the unskilled workers employed by the Ankerbrotfabrik, the nearby South Railway Station (Südbahnhof), and the cable factory, Felten und Guilleaume. [...] With few parks in the area, the children were forced to play in the narrow, dirty, and often dangerous streets. A 1912 report by Favoriten's city advisor complained about the rubbish and dust from the cable factory and rat-infested trash storage areas, which forced residents to keep their windows closed. (Wegs 25-6)

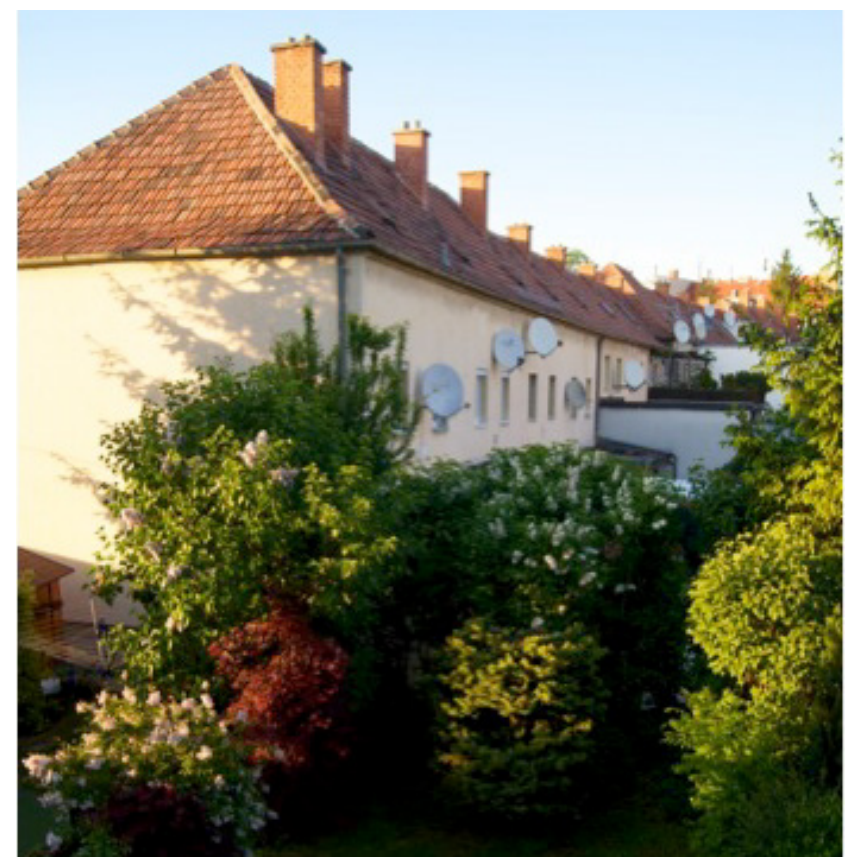

Fig. 8 Laaerberg backyard 


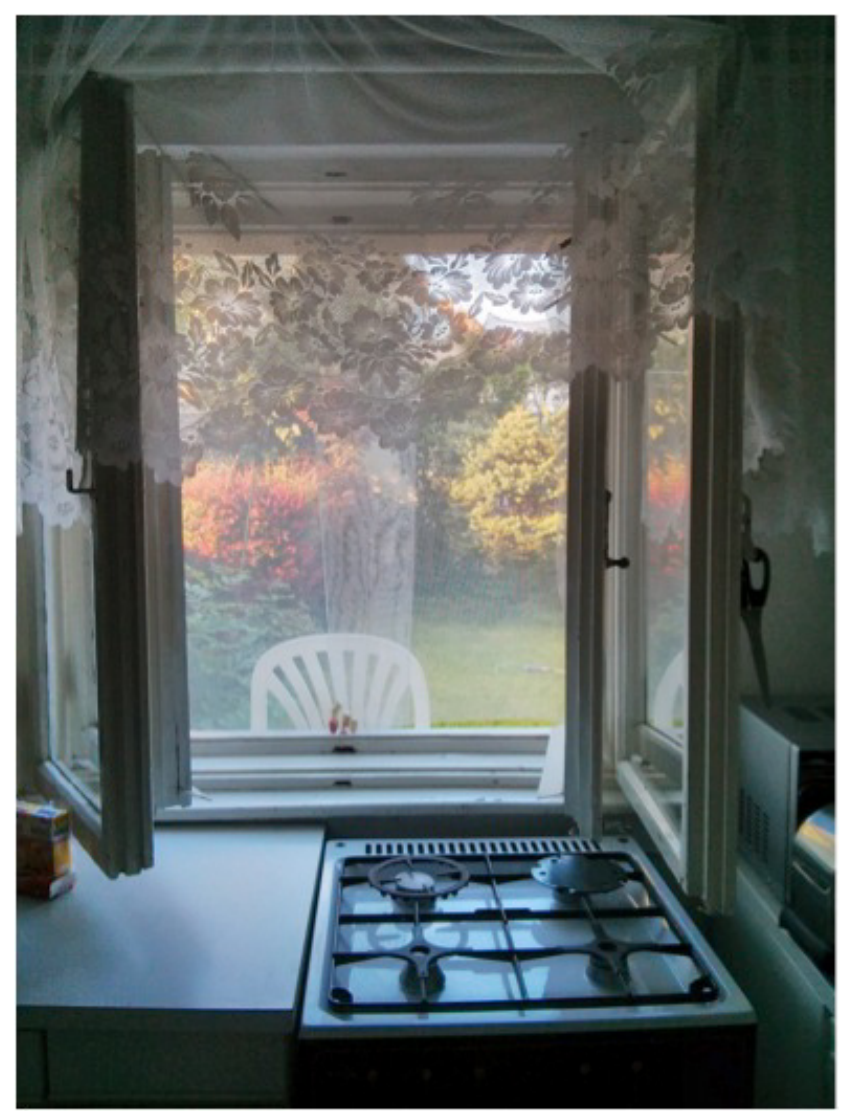

Fig. 9 View out window

Because of the terrible housing shortage and the inadequacy of the existing housing on the city's periphery, "the Social-Democrat-controlled city council launched a major building program in the interwar period. They reduced rents to such levels that private investors were driven out of the market.... But the SDAP was interested in more than merely providing housing for the poor. In their drive to create 'new people,' socialist leaders hoped to mould a new worker consciousness through a multitude of cooperative projects in the new housing projects, such as common kitchens, daycare centres, kindergartens, and numerous evening events" (Wegs 38). That is, the area around where Kertész was filming his monumental films was soon being scouted out by city planners and architects such as Adolf Loos, who was responsible for encouraging the building of humane row houses which were equipped with gardens in the back so that vegetables could be passed conveniently into the new Frankfurt-style kitchens [Figs. 8, 9].

Perhaps it was Kertész's status as an immigrant in Vienna that gave him greater insight into, and empathy with, the plight of the masses there and the role that industry, including the cultural industries, could play in improving their working and living conditions, and which, as history has established, was indeed reasonably effective.[5] Favoriten has remained predominantly ethnic and working class, but, according to recent headlines, "ausländermäßig funktioniert's!" (foreigner-wise, it works, Gučanin and Puktalović). Also noteworthy is the fact that, unlike Lang, Curtiz went to Hollywood on his own volition, in 1926, at the behest of Warner Bros, a move very much in keeping with an awareness of technology's ability to provide better life chances.

\section{Curtiz's New World Film and its Location}

If we turn now to what has become Kertész's best-known work, the 1942 Casablanca, we find a pattern similar to the one in his earlier monumental film. Once again we have the story of a woman under great external pressure to play the temptress and use her feminine charms for the benefit of others. Again her loyalties and desires are divided, and it is left up to her to decide what the right thing to do is so that she doesn't regret it: "Maybe 
not today, maybe not tomorrow, but soon and for the rest of your life." [6] And again access to technology proves not oppressive or destructive but rather enabling, indeed pivotal at the film's climax, as a bulky plane provides the means of escape out of a doomed city.

The city in Casablanca is as interesting as the female lead in its parallels to Sodom und Gomorrha. Also a peripheral location, on the edge of the main theatres of WWII, it resembles Vienna/ Sodom in that it is depicted as under the control of a sinful, evil force, and it also features a metonymic den of iniquity. Consideration of Kertész's earlier film thus implicitly situates Nazi-occupied Casablanca in a continuum that stretches back to include the worship of false idols in antiquity and the robber-baron capital crisis in the early twentieth century. If Alan K. Rode's assessment is correct that "Inexplicably, no other director remotely possessing [Curtiz's] credentials has been accorded less historical respect,"[7] the same claim can also be made of Sodom und Gomorrha, especially if one keeps in mind that Metropolis's way of vilifying "active and destructive female sexuality" by pairing it with "the destructive potential of technology... is in no way unique to Lang's film. Apart from... literary examples..., it can be found in numerous 19th-century allegorical representations of technology and industry as woman" (Huyssen 77). Rather than the usual eruptions of nature into the heart of the metropolis in the form of wild animals or storms that then need to be tamed in order to restore bourgeois order, which one finds in, for example, King Kong,
Kertész's films offer an emancipatory reversal: insertions of the technological into the wild nature on the metropolis's periphery that open up lines of flight for those excluded from or trapped in the lower orders of oppressive hierarchies. That such a depiction is implicitly antinational is underscored by Catherine Portuges, who describes Casablanca as " $\mathrm{t}]$ he most international of productions, a film about anti-fascism, directed by a Hungarian, with a cast... most of whom speak accented English," and the one who mostly notably does not, Humphrey Bogart's Rick, when asked his nationality, responds "I'm a drunkard" (Portuges 166).

What I would like to underscore here in concluding is the potential that Kertész saw in outskirts and peripheries when one had access to adequate technological means to transform them. That is what he discovered upon arriving in both Vienna and Hollywood: that to approach the centre, one had to look to the edges, of cities as well as of regions and continents; that was where one could find the paths to the greatest success, at least that is where, as I hope to have established with this contribution, the paths to his greatest successes were located. 


\section{Endnotes}

[1] He was born Mihály Kaminer in Budapest in 1888 and worked there in theater and film as Mihály Kertész before fleeing in 1919 for Vienna (Portuges 161).

[2] The original version was 3,945 metres long, representing a running time of about 178 minutes (Wostry 163). The film was therefore generally shown in two parts: Part I: Die Sünde ("The Sin") and Part II: Die Strafe ("The Punishment"). For details about what made the restoration of the film one of the most difficult cases in Austrian film history despite there being more material for it than for any other Austrian silent film (copies were found in archives in Moscow, Berlin, Prague, Bologna and Milan), see Wostry. "Although the whole film is not recovered, all four sequences have now been restored. The restored version has a running time of 98 minutes" (cf. the English Wikipedia entry).

\section{[3] As Armin Loacker and Ines}

Steiner have shown, in these films the medium was really the message (11). In early monumental films, audiences encountered founders of religion like Buddha, Moses and Jesus; historical heroes like Hannibal, Belsazar, Caesar, Mark Anthony, Nero, Spartacus, Alexander, Columbus, Danton, and Napoleon; legendary femmes fortes like Cleopatra, Judith, Esther, Kriemhild, Joan of Arc, Maria Stuart, Anne Boleyn; and femmes fatales like Salome, Delilah, the Queen of Saba, Lucrezia Borgia, and Mme. Dubarry (11). In contrast to film critics such as Kracauer, who dismissed early monumental film as problematic, escapist, aesthetically questionable and "unfilmic" (12), the work in Loacker and Steiner's Imaginierte Antike (Imagined Antiquity) shows that early film became not simply "the image repository of modernity" but rather "the primary medium in which this modernity preserved images of everything that had been" because it was suited to create "all possible, real and imaginary images in collective memory" (11).

[4] I have left Vorstadt untranslated in order to highlight the specificity of the "before the city" aspect of the Viennese situation, which in the original German is in the singular. One could translate Vorstadt as "outer district," but then the singularity of the original space would go lost. By the same token, it would be culturally misleading to call Favoriten a suburb.

[5] Portuges comments on "Curtiz's multiple--and conflicted--identities as a Hungarian Jew, European intellectual, and Hollywood icon" and relates a wonderful anecdote about his "otherness as a foreigner" which has "Curtiz and Lagosi speaking Hungarian in a café in Los Angeles in the 1930s; their loud conversation purportedly prompted Billy Wilder to admonish them: 'Enough Hungarian, boys! You're in America, so you should talk in German" (164).

[6] As Catherine Portuges points out, "A number of Curtiz's films, such as Mildred Pierce (1945)... later an iconic text of feminist film theory--portray intelligent, resourceful and ambitious women, clever survivors who may be allowed to love more than one man at a time" (165). 
[7] Something he details in his biography: "Curtiz directed more acclaimed movies in different styles and genres than any other film director. He directed over 170 feature films, a staggering output that outstrips the legendary John Ford and exceeds the combined careers of George Cukor, Victor Fleming and Howard Hawks. Nominated five times by the Motion Picture Academy as Best Director and winning for Casablanca, Curtiz helmed rousing adventures, westerns, musicals, spectacles, drama, comedies, horror, war, crime, mystery and film noir. His career shaped the earliest days of silent cinema in Europe as he acted, produced and directed scores of films in Budapest, Vienna and France before coming to Warner Brothers in 1926."

\section{Works Cited}

Dassanovsky, Robert. "Home/Sick: Locating Billy Wilder's Cinematic Austria in The Apartment, The Private Life of Sherlock Holmes, and Fedora." Journal of Austrian Studies 46.3 (Fall 2013): 1-25. Print.

Gučanin, Jelena and Siniša Puktalović. "Lokalaugenschein in Wien Favoriten: «Ausländermäßig funktioniert s!!» daStandard.at. 21 Oct. 2013, accessed 21 Oct. 2013.

Huyssen, Andreas. After the Great Divide: Modernism, Mass Culture, Postmodernism. Bloomington and Indiana: Indiana UP, 1986. Print.

Loacker, Armin. "Werkstätten der Seh(n)sucht: Produktionsgeschichte und Produktionsstrukturen des Monumentalfilms in Österreich."
Imaginierte Antike: Österreichische Monumental-Stummfilme. Eds. Armin Loacker and Ines Steiner. Vienna: Filmarchiv Austria, 2002. 21-40. Print.

Loacker, Armin and Ines Steiner, eds. Imaginierte Antike: Österreichische Monumental-Stummfilme. Vienna: Filmarchiv Austria, 2002. Print.

Maderthaner, Wolfgang, and Lutz Musner. Die Anarchie der Vorstadt: Das andere Wien um 1900. Frankfurt am Main; New York: Campus, 1999. Print.

Michael Curtiz: The Greatest Director You Never Heard Of. Dir. Gary Leva. Leva FilmWorks, 2012.

Nord, Cristina. "Opulente Götzendienste: Michael Kertész' Sodom und Gomorrha." Sodom und Gomorrha, derstandard.at 2002. DVD accompaniment.

Portuges, Catherine. "Curtiz, Hungarian Cinema, and Hollywood." Comparative Hungarian Cultural Studies. Eds. Steven Tötösy de Zepetnik and Louise O. Vasvári. Boston: Purdue University Press, 2011. 161-70. Print.

Robertson, James C. The Casablanca Man: The Cinema of Michael Curtiz. London: Routledge, 1993. Print.

Rode, Alan K. "Michael Curtiz: A Man for All Movies." <http://alankrode. com/public2/index.php/latest-news/ bio/arthurlyons/photogal/vig/top10/ appearances/resources/menu-separator/ work-in-progress-biography-of-michaelcurtiz>, accessed 15 June 2013.

Wegs, J. Robert. Growing Up Working 
Class: Continuity and Change Among

Viennese Youth, 1890-1938. University

Park, PA: Pennsylvania State University

Press, 2008 (1989). Print.

Wostry, Nikolaus. "Sodom und

Gomorrha oder vom Reiz der

Kürze. Anmerkungen zu einer

Rekonstruktion." Imaginierte Antike:

Österreichische Monumental-Stummfilme.

Vienna: Filmarchiv Austria, 2002. 163-73.

Print.

\section{Image Notes}

Clip 1 Sodom und Gomorrha (Images @1922 Sascha-Film).

Clip 2 Sodom und Gomorrha (Images @1922 Sascha-Film).

Fig 1 "Mary Conway," Sodom und Gomorrha (Images @1922 Sascha-Film).

Fig 2 "Harry Lighton," Sodom und Gomorrha (Images @1922 Sascha-Film).

Fig 3 "Mr. Harbers," Sodom und Gomorrha (Images @1922 Sascha-Film).

Fig 4 "Filmstadt" (Photo: S. Ingram)

Fig 5 "Kurpark Oberlaa" (Photo: S. Ingram)

Fig 6 "Filmpark" Web. July 10, 2013 $<$ http://maps.google.com>

Fig 7 "Artificial pond on the Laaerberg, 1910" (Favoriten Album 1880-1930. Eds. Helfried Seemann and Christian Lunzer. Vienna: REMAprint, 1992. n.p.).

Fig 8 "Laaerberg backyard" (Photo: S. Ingram)

Fig 9 "View out window" (Photo: S. Ingram)
Susan Ingram is Associate Professor in the Department of Humanities at York University, Toronto, where she is affiliated with the Canadian Centre for German and European Studies and the Research Group on Translation and Transcultural Contact. She is the general editor of Intellect Book's Urban Chic series and the editor of the World Film Locations volume on Berlin.

Susan Ingram est professeure associée au Department of Humanities de l'université York, à Toronto. Elle y est affiliée au Canadian Centre for German and European Studies, et au Research Group on Translation and Transcultural Contact. Elle est rédactrice en chef de la série Intellect Book's Urban Chic, et a dirigé le volume sur Berlin de la série World Film Locations.

This article is licensed under a Creative Commons 3.0 License although certain works referenced herein may be separately licensed, or the author has exercised their right to fair dealing under the Canadian Copyright Act.

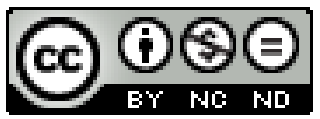

